\title{
Cytokine profile in Typhoid fever: correlation with clinical features and sensitivity patterns
}

Zulfiqar A. Bhutta

\begin{abstract}
Abstrak
Kami telah melaporkan sebelumnya kenaikan bermakna konsentrasi interleukin (IL)-6 dan Tumor Necrosis Factor (TNF) - $\alpha$ dalam serum demam tifoid dan hubungannya dengan angka kekambuhan. Pada studi ini, kami akan mengevaluasi kadar sitokin pro inflammatory IL-I $\beta, I L-6$ dan TNF- $\alpha$ dalam plasma, juga reseptor IL-1 antagonis (IL-Ira), reseptor IL-6 yang dapat larut (IL-6sR) dan reseptor TNF p55 yang dapat larut (sTNF p55r) pada anak-anak dengan kultur terbukti tifoid pada saat masuk Rumah Sakit. Dibandingkan dengan kelompok kontrol, yaitu anak-anak dengan infeksi bakteri non-tifoid dan demam, ditemukan peningkatan secara bermakna konsentrasi IL-I $\beta$ dan IL-6 pada anak dengan kultur terbukti tifoid, sedangkan nilai TNF- sebanding pada kedua kelompok tersebut. Anak dengan tifoid juga mempunyai konsentrasi sTNFp55r dan IL-Ira lebih tinggi tetapi tidak demikian halnya dengan IL-6sR. Dibandingkan dengan tifoid yang sensitif, anak dengan tifoid MDR mempunyai penyakit lebih parah dengan peningkatan secara bermakna protein plasma c-reactive ( $83 \# 66$ versus $51 \# 45 \mathrm{mg} / L, p<05$ ) dan peningkatan konsentrasi $I L-6, I L$-Ira dan sTNFp 55 r. Konsentrasi sitokin plasma berkorelasi erat dengan toksisitas klinis dan menurun secara bermakna setelah 72 jam terapi anti mikroba. Data kami menunjukkan bahwa dibandingkan dengan galur tifoid sensitif, tifoid MDR menyebabkan penyakit yang lebih berat pada anak-anak dengan toksisitas klinis dan respon sitokin sistemik lebih besar. Hal tersebut mungkin berperan dalam relatif lambatnya respon terhadap terapi dan penurunan panas serta lebih sering terjadinya perburukan keadaan pada anak-anak tersebut.
\end{abstract}

\begin{abstract}
We have previously reported significant elevation of serum interleukin (IL)-6 and tumor necrosis factor (TNF) - $\alpha$ concentrations in typhoid fever and a relationship with relapse rates. In the present study we prospectively evaluated admission plasma concentration of pro-inflammatory cytokines $I L-I \beta, I L-6$ and $T N F-\alpha$ as well as $I L-1$ receptor antagonist (IL-Ira), soluble IL-6 receptor (IL-6sR) and soluble TNF 555 receptor (sTNF p55r) in children with culture-proven typhoid. In comparison with a control group of children with non-typhoidal bacterial infections and febrile illnesses, children with culture proven typhoid had significantly elevated concentrations of $I L-I$ and IL- 6 at admission whereas values for TNF- $\alpha$ were comparable. However, children with proven typhoid also had higher concentrations of sTNFp55r and IL-Ira but not IL-6sR at admission. In general, in comparison with sensitive-typhoid, children with MDR typhoid were more severely ill with significantly higher admission plasma $C$-reactive protein ( $83 \# 66$ versus $51 \# 45 \mathrm{mg} / \mathrm{L}, \mathrm{p}<0.05$ ) and had comparatively higher admission concentrations of IL-6; IL-Ira and sTNFp55r. Plasma cytokine concentrations correlated most closely with clinical toxicity at admission and reduced significantly by 72 hours of antimicrobial therapy. Our data indicate that in comparison with sensitive strains of typhoid, MDR typhoid is a more severe illness in childhood with greater clinical toxicity and systemic cytokine response. This may account for the comparatively slower response to therapy and defervescence as well as higher rates of adverse outcome in these children.
\end{abstract}

Department of Paediatrics, The Aga Khan University, Karachi, Pakistan. 